Reprod. Nutr. Dévelop., 1988, 28 (5), 1283-1299

\title{
A ram epididymal secretory protein shares common anti- genic determinants with rat epididymal proteins and human seminal plasma proteins
}

\author{
S. FOURNIER-DELPECH $\left({ }^{1}\right),\left({ }^{2}\right)$, M. K. HOLLAND $\left({ }^{3}\right)$, M. D. SKUDLAREK $\left({ }^{3}\right)$,
} T. L. RANKIN $\left({ }^{3}\right)$, Marie-Claire ORGEBIN-CRIST $\left({ }^{3}\right)$, M. COUROT $\left({ }^{1}\right)$

(') I.N.R.A., Station de Physiologie de la Reproduction Nouzilly 37380 Monnaie $F$.

${ }^{2}$ ) C.N.R.S., 15, Quai Anatole-France, Paris.

( $\left.{ }^{3}\right)$ Center for Reproductive Biology Research, Vanderbilt Univ. Nashville 37232 USA

Mammalian spermatozoa leave the testis as immature cells unable to fertilize until they have traversed the epididymis. Sperm maturation is an orchestrated series of sequential events occurring at different levels of the epididymis: sperm-zona pellucida binding ability in the proximal epididymis, progressive motility and the ability to penetrate and fertilize the oocyte in the middle epididymis and the ability to initiate normal embryonic development in the distal epididymis (see reviews by Orgebin-Crist, 1986; Amann, 1987; FournierDelpech and Courot, 1987). In parallel, spermatozoa undergo a variety of surface changes (Hammerstedt and Parks, 1987). Although the functional significance of these changes has not been elucidated, it is believed that some could be related to the processes of sperm maturation. Sperm maturation itself is dependent upon androgen-controlled secretory products of the epididymal epithelium (see review by Orgebin-Crist, 1986). Since inhibitors of protein synthesis block the acquisition of fertilizing ability within the epididymis, particular attention has been focused on epididymal proteins which are secreted upon androgen stimulation and which intereact with the maturing spermatozoa. Such proteins could mediate the androgenic regulation of fertilizing ability of the spermatozoa.

The rat epididymis synthesizes specific proteins under testosterone stimulation which have an affinity for immature spermatozoa from the testis or the proximal epididymis. One such protein migrates in the pre-albumin area on non-denaturing polyacrylamide gel electrophoresis and, therefore, has been called prealbumin epididymal specific (PES) (Fournier-Delpech, Bayard and Boulard, 1973). This rat PES protein has been studied under a number of other names : acidic epididymal glycoprotein (AEG) (Lea et al., 1978, SEP (Kohane et al., 1979), SP (Faye et al., 1980), $32 \mathrm{kD}$ protein (Wong and Tsang, 1982), proteins D and E (Garberi et al., 1979). The PES protein, which apparently has two components (Garberi et al., 1979 ; Brooks et al., 1986), has been immunolocalized on the epididymal epithelium and has been shown to bind to a restricted region of the sperm head. Recently, from amino acid sequence data, Brooks et al. (1986) have shown that these proteins are homologous with carboxypeptidase $Y$, although they do not express this enzyme activity. In the ram there is a protein of 
$64 \mathrm{kD}$ molecular weight which runs in the prealbumin region on non-denaturing gels. The protein, synthesized by the epididymis under testosterone stimulation, binds to the plasma membrane covering the acrosome of immature testicular ram spermatozoa and is still present after ejaculation. This protein could thus be involved in sperm-egg interaction at fertilization (Fournier-Delpech et al., 1981 ; Jones, Fournier-Delpech and Willadsen, 1982 ; Fournier-Delpech et al., 1988).

In this paper we present information on common antigenic determinants shared by androgen-dependent epididymal proteins in the rat (rat PES $32 \mathrm{kD}$ ) and the ram (ovine PES $64 \mathrm{kD}$ ) and also by human seminal plasma proteins.

\section{Materials and methods.}

\section{Materials.}

Animals : Epididymides were obtained from three adult lle-de-France rams in breeding season and from 50 adult Wistar male rats (I.N.R.A. strain). Samples of human seminal plasma were provided by 10 donors of proven fertility.

Products were from Roussel-Uclaf (testosterone implants of $200 \mathrm{mg}$ each), Vecta Laboratories (Vecta Stain, ABC kit) Sigma and Prolabo (other products).

\section{Methods}

\section{a. Protein purification.}

1. Ovine PES $64 k D$. - The rams were orchidectomized and 45 days later the left epididymis was removed. A sample of epididymal region 3 (Jones, FournierDelpech and Willadsen, 1982) was prepared for electron microscopy (see below). At the same time a testosterone implant $(200 \mathrm{mg})$ was placed under the thorax skin. Three weeks later the right epididymis was removed and a piece of region 3 was also prepared for electron microscopy. After removal of the connective tissue envelope the remaining tissue was used for purification of Ovine PES 64 kD (Fournier-Delpech et al., 1988). Briefly, the tissue was homogenized in saline and $\mathrm{SO}_{4}\left(\mathrm{NH}_{4}\right)_{2}$ added to a final concentration of $25 \%$ $(\mathrm{w} / \mathrm{v})$. After centrifugation, the supernatant was dialyzed against Tris- $\mathrm{HCl}$ buffer (10 mM, pH 8.8-9) and passed over a DEAE-Sephacel column. Proteins eluted by $0.3 \mathrm{M} \mathrm{CINa}$ were submitted to preparative electrophoresis on non-denaturing polyacrylamide slab gels ( $7 \%$ acrylamide, Tris-glycine buffer at $\mathrm{pH} 8.3$ ). The PES was electroeluted, dialyzed against $\mathrm{CO}_{3}\left(\mathrm{NH}_{4}\right)_{2} 10 \mathrm{mM}$ and lyophilized.

2. Rat PES $32 \mathrm{kD}$. - Forty-five (45) rats were orchidectomized and 45 days later a testosterone implant $(10 \mathrm{mg})$ was placed under the skin of the thorax. Three weeks later, the epididymides were removed, homogenized in cold saline, centrifuged $(30,000 \mathrm{~g} \times 1$ hour $)$, and the supernatant passed through a column of Concanavalin A-agarose. Glycoproteins were eluted by $\alpha$-2-methyl-mannose ( $5 \%$ in aceto-acetic buffer, $0.1 \mathrm{M}, \mathrm{pH} 5.6$ containing $5 \mathrm{mM} \mathrm{CaCl} 2$ and $\mathrm{MgCl}_{2}$ ), dialyzed against Tris- $\mathrm{HCl}$ buffer $(10 \mathrm{mM}, \mathrm{pH} 8.8-9)$ and were fractionated on 
polyacrylamide slab gels under non-denaturing conditions ( $7 \%$ acrylamide Tris-glycine buffer, $\mathrm{pH}$ 8.3). Protein $\mathrm{D}$ was separated from protein $\mathrm{E}$, electroeluted, and lyophilized after extensive dialysis against $\mathrm{CO}_{3}\left(\mathrm{NH}_{4}\right)_{2}$.

3. Human seminal plasma proteins. - Samples of seminal plasma, after liquefaction, were treated with sodium azide $(0.3 \%$ final) and centrifuged $(800 \mathrm{~g} \times 30 \mathrm{~min})$. The supernatants were pooled and centrifuged at $120,000 \times \mathrm{g}$ for 1 hour. The supernatant was dialyzed against Tris- $\mathrm{HCl}$ buffer $(10 \mathrm{mM}$, $\mathrm{pH}$ 8.8-9) and submitted to preparative gel electrophoresis. The proteins were either transferred to nitrocellulose sheets or electroeluted, dialyzed, and lyophilized.

\section{b. Electron microscopy.}

Samples of ram epididymal region 3 were fixed in glutaraldehyde $(2.5 \%$ in cacodylate buffer $0.1 \mathrm{M}, \mathrm{pH} 7$ ), embedded in Epon, stained with uranyl acetate and lead citrate, and viewed with a transmission electron microscope.

\section{c. Immunological procedures.}

1. Preparation of antisera against ovine PES $64 \mathrm{kD}$. - Pre-immune sera were obtained from 2 female adult rabbits, pooled, and frozen. The animals then received $50 \mu \mathrm{g}$ of protein in 15 subcutaneous injection sites at days $0,8,15$, and 22. The first injection was made with Complete Freund Adjuvant; the following injections were made with Incomplete Freund Adjuvant. At day 30, the rabbits were bled and the sera prepared. The preimmune and immune sera were diluted with $8 \% \mathrm{BSA}$, incubated overnight at $4{ }^{\circ} \mathrm{C}$, and centrifuged $(120,000$ $\times \mathrm{g} \times 1$ hour) to discard the precipitated proteins, if any. The supernatants were sterilized by filtration, split into aliquots, and frozen. In some experiments, instead of preimmune sera non-immune sera were used. No positive reaction to the antigen was detected with either sera.

2. Immunoblotting. - Rat caudal fluid was diluted in saline, centrifuged $(800 \times \mathrm{g} \times 30 \mathrm{~min})$ and the supernatant adjusted with $3 \mathrm{M}$ Tris- $\mathrm{HCl}$ buffer at $\mathrm{pH} 8.8$ to $10 \mathrm{mM}$ final. Protein samples $(100 \mu \mathrm{g} / 50 \mu \mathrm{l}$ in Tris- $\mathrm{HCl}$ buffer $)$ were run on non-denaturing slab gels ( $7 \%$ acrylamide, Tris-glycine buffer at $\mathrm{pH} 8.3$ ) with 2 -h pre-electrophoresis. The proteins were transferred in potassium phosphate buffer $(50 \mathrm{mM}, \mathrm{pH} 7.5)$ containing EDTA $(2 \mathrm{mM})$ and $\mathrm{CINa}(50 \mathrm{mM})$ to 2 nitrocellulose sheets by the sandwich method. The blots were treated in parallel with non-immune and immune sera diluted at $1 / 500$. Goat anti-rabbit immunoglobulins labeled with the biotin-avidin horseradish peroxidase complex (Vecta Stain $\mathrm{ABC}$ kit) were visualized with diaminobenzidine $\mathrm{HCl}$ in presence of $\mathrm{Cl}_{2} \mathrm{Ni}$. Tween $(0.2 \%)$ was added to all steps until the second antibody reaction.

\section{Immunocytochemistry.}

Spermatozoa: Ram spermatozoa from the rete testis or the cauda were washed with medium 199 and incubated with non-immune or immune sera $(1 / 200)$ in medium containing $1 \%$ goat serum. They were in turn incubated for 1 hour with goat anti-rabbit IgG labeled with peroxidase, washed in medium 199 , and stained with diaminobenzidine $\mathrm{HCl}$ in the presence of $\mathrm{Cl}_{2} \mathrm{Ni}$. 
Testicular and epididymal tissues: Rat testis and epididymis were removed, fixed in paraformaldehyde (4\%)-glutaraldehyde (2\%) containing picric acid $(0.2 \%)$, and embedded in paraffin. Sections were treated with xylene to eliminate the paraffin, washed in absolute ethanol, and rehydrated with decreasing concentrations of ethanol in water. They were then treated with goat serum (1\%) in Tris- $\mathrm{HCl}$ containing $0.2 \%$ Tween and $0.1 \%$ SDS and non-immune or immune serum at $1 / 200$ for 1 hour. The rabbit IgG were revealed with Vecta Stain ABC kit used according to the manufacturer's instructions.

\section{d. Analytical procedures.}

1. SDS polyacrylamide ge/ electrophoresis. - 1-D SDS electrophoresis was performed as previously described (Jones, Fournier-Delpech and Willadsen, 1982) on slab polyacrylamide gel containing $15 \%$ acrylamide at $\mathrm{pH} 8.3$.

2-Dimensional SDS electrophoresis: Protein samples $(100 \mu \mathrm{g} / 15 \mu \mathrm{l})$ were denatured with $10 \mu \mathrm{l}$ of $9 \mathrm{M}$ urea, $1 \%$ SDS, Tris- $\mathrm{HCl} 10 \mathrm{mM}$ at $\mathrm{pH} 7.4,5 \%$ mercaptoethanol, subjected to isoelectrofocusing in tube gels using ampholine $\mathrm{pH}$ range of 3.5 to 10 . The second dimension was run on $18 \times 18 \times 0.15 \mathrm{~cm}$ slab gels consisting of a linear gradient from 8 to $13 \%$ acrylamide according to the method of O'Farrell. Gels were stained with Coomassie Brillant Blue R 250 or ammoniacal silver.

2. Amino acid analysis. - Rat PES $32 \mathrm{kD}$ and ovine PES $64 \mathrm{kD}$ were electroeluted from the corresponding single spots after 2-D SDS polyacrylamide gel electrophoresis and staining with ammoniacal silver. Amino acid analysis was performed on a Waters Picotag Amino Acid analyzer. Amino acids per mole of protein were deduced from the molecular weights after substraction of glycosidic residues : $7.5 \%$ (data from Lea, Petrusz and French, 1978) for rat PES $32 \mathrm{kD}$ and $4.5 \%$ for the ovine PES $64 \mathrm{kD}$ (unpublished data).

\section{Results.}

a. Morphology of the epididymis from which ovine PES $64 k D$ was purified.

Regressive changes in the epididymal epithelium were noted 45 days after castration : reduction in the size of the stereocilia border and the cytoplasm and decrease in cell height. The nucleus occupied approximately half of the cell (fig. 1.1). The effect of testosterone supplementation is illustrated on figure 1.2. The supranuclear cytoplasm was more developed and the apical surface of the cells had long stereocilia.

\section{b. Electrophoretic characteristics of ovine PES $64 \mathrm{kD}$ compared with rat PES $32 \mathrm{kD}$.}

The characteristics of the ovine PES $64 \mathrm{kD}$ migrating in the prealbumin area are illustrated in figure 2. Purified ovine PES $64 \mathrm{kD}$ (fig. 2A) migrated with molecular weight $64,000 \mathrm{kD}$ on 1-D SDS-polyacrylamide slab gel (fig. 2B); after 

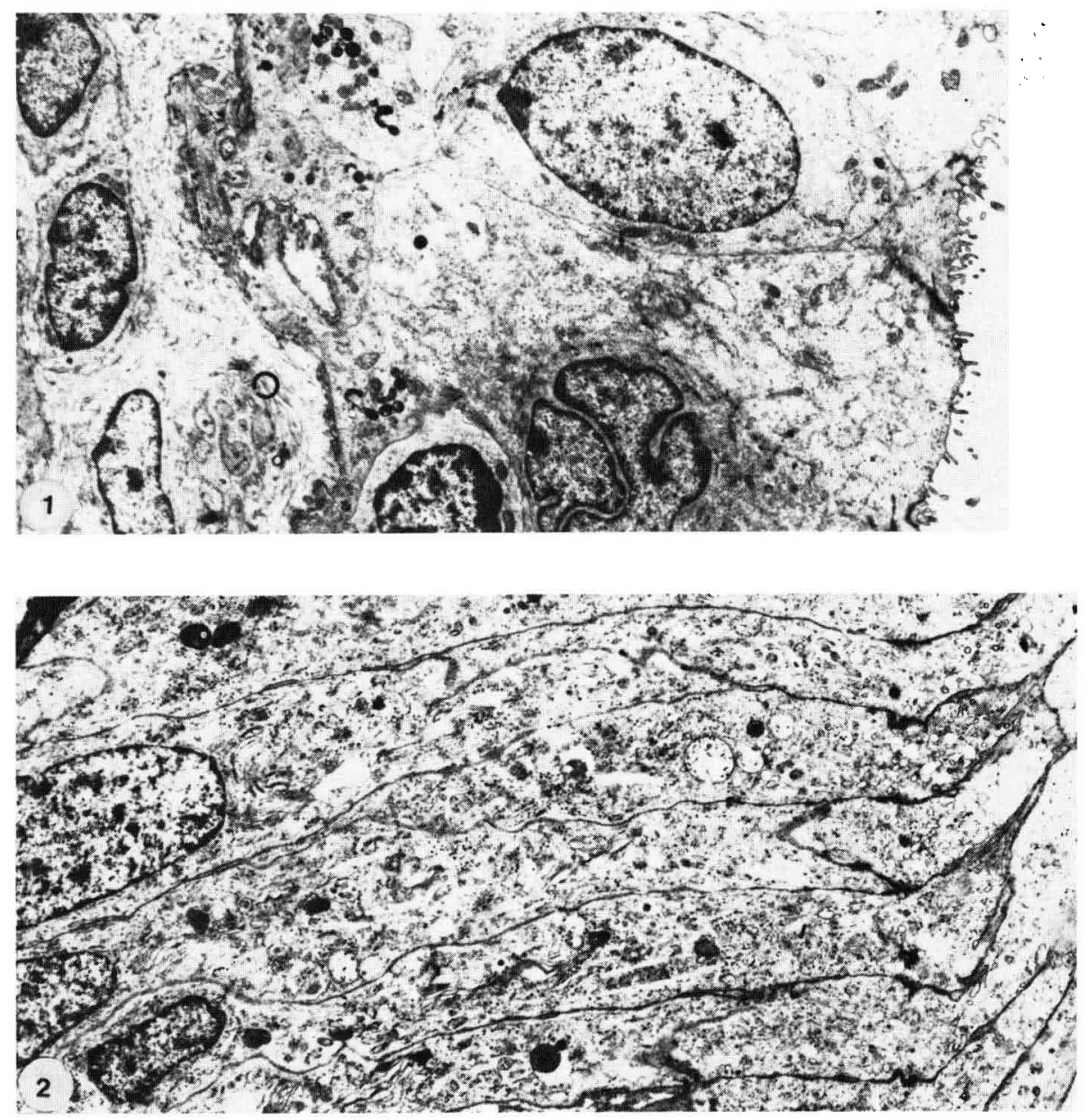

FIG. 1. - Androgendependency of the epididymis in the ram: effects of the testosterone on the epithelium in the castrate.

FIG. 1.1: Epithelium lining the duct of the left epididymis in ram castrated along 45 days $(\times 1400)$.

FIG. 1.2: Epithelium lining the duct of the right epididymis in the same ram 3 weeks after the deposit of the testosterone implant : note the development of the supranuclear cytoplasm and the stereocilia ( $\times 1400)$

denaturation with urea, the apparent molecular weight was $57,000 \mathrm{kD}$ after 2-D SDS electrophoresis and the isoelectric point was 7 (fig. 2C). The rat PES $32 \mathrm{kD}$ migrated in a similar position to protein $\mathrm{D}$ (fig. 2D), that is, as a single band of molecular weight $32,000 \mathrm{kD}$ on 1-D SDS polyacrylamide slab gel (fig. 2E). After urea denaturation and electrofocusing, it migrated on 2-D SDS polyacrylamide gel with a molecular weight of $27,000 \mathrm{kD}$ and an isoelectric point 5.3 (fig. 2F). 


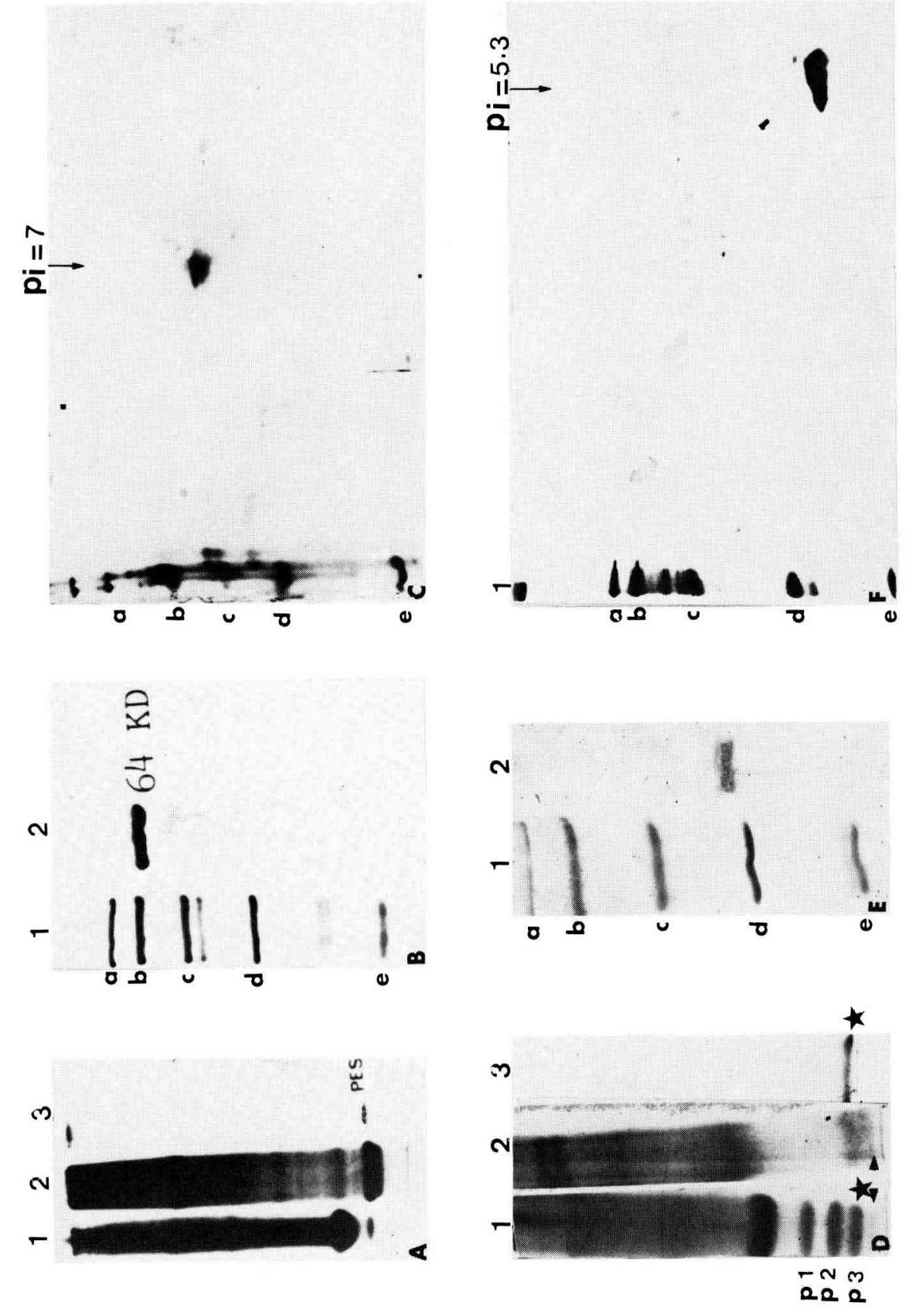




\section{c. Immunocytochemical localization of ovine PES $64 k D$ antigenic determinants.}

The anti-ovine PES $64 \mathrm{kD}$ serum (fig. 3.II.1) cross-reacted with the rat PES electroeluted from 2-D gels or the proteins $D$ and $E$ present in the epididymal fluid. Slight staining of the protein $\mathrm{C}$ was also detected (fig. 3.II.2 and 3.II.4). Furthermore, the ovine antibody reacted with three human seminal plasma proteins identified by their relative coefficient of mobility in relationship to albumin : $0.46,0.63,0.80$ (fig. 3.1 and $3.11 \mathrm{I}$ ). Reaction with rat protein $\mathrm{C}$ and human protein 0.46 was nonspecific, since the non-immune serum also reacted with them (fig. 3.I.2 and 3.1.3). Therefore, rat proteins $D$ and $E$ and human proteins 0.63 and 0.80 , that reacted with the antibody against ovine PES $64 \mathrm{kD}$ and not with the non-immune serum, shared common antigenic determinants with ovine PES $64 \mathrm{kD}$.

Human protein 0.63 characterized on 2-D SDS polyacrylamide gel electrophoresis had 3 components $(16,000 \mathrm{kD}, 35,000 \mathrm{kD}$, and $53,000 \mathrm{kD}$ at isoelectric point 5.5 and one component $(16,000 \mathrm{kD})$ at isoelectric point 5 . Human protein 0.80 under the same conditions had 2 components of approximately $40,000 \mathrm{kD}$ and isoelectric point 5.5 .

1. Localization on ram spermatozoa. - The antibody against ovine PES 64 kD reacted positively with the midpiece of ram spermatozoa from the testis, epididymis, or ejaculate and with the periacrosomal area of spermatozoa from the epididymis or the ejaculate. The pre-immune serum reacted positively with the sperm mid-piece. Therefore, only the periacrosomal surface; had antigenic determinants common to the secreted ovine PES $64 \mathrm{kD}$ protein. This antigen appeared on the spermatozoa in the epididymis and remained on ejaculated spermatozoa (fig. 4: 1 to 4 ). It was localized on the plasma membrane (fig. 4-6).

FIG. 2. - Electrophoretic pattern of the ovine PES $64 k D$ and rat PES $32 \mathrm{kD}$ proteins.

- A and D : Non denaturing electrophoresis (7\% acrylamide, $\mathrm{pH} 8.3$ ) of:

A : Ram proteins : 1 = Proteins of the epididymal fluid ; $2=$ DEAE-Sephacel fraction $0.3 \mathrm{M} \mathrm{CINa} \mathrm{;}$ $3=$ Purified ovine PES

D : Rat proteins: $1=$ Proteins of the epididymal fluid: prealbumin $1(p 1), 2(p 2), 3(p 3)$; $2=$ Con A-Agarose fraction eluted by $\alpha 2$-D-methylmannose : protein $D(\star)$ and $E(\mathbf{\Lambda}) ; 3=$ Purified rat PES $32 \mathrm{kD}$.

- $B$ and $E: 1-D$ SDS polyacrylamide gel electrophoresis (15\% acrylamide, $\mathrm{pH} 8.3$ ) of purified PES proteins having molecular weight $64 \mathrm{kD}$ in the ram $\left(E_{2}\right)$ and $32 \mathrm{kD}$ on the rat $\left(E_{2}\right)$ refering to the standardized molecular weights under number 1 .

- C and F : 2-D SDS polyacrylamide gel electrophoresis ( 8 to $13 \%$ acrylamide, $\mathrm{pH} 3$ to 10 ) of the purified PES having molecular weight $57 \mathrm{kD}$ at isoelectric point 7 in the ram (C), and $27 \mathrm{kD}$ at isoelectric point 5.3 in the rat (F) refering to standardized molecular weights under number 1. Standardized molecular weights were: 94 kD (a), 67 kD (b), 45 kD (c), 30 kD (d), 20 kD (e). Gels A, B, D and E were stained with Coomassie R 250 brillant blue, gel $C$ and $F$ with ammoniacal silver. Note that the purified rat PES and ovine PES present under number 3 on panels $A$ and D, migrated as a single spot on 2-D SDS polyacrylamide gel electrophoresis. 


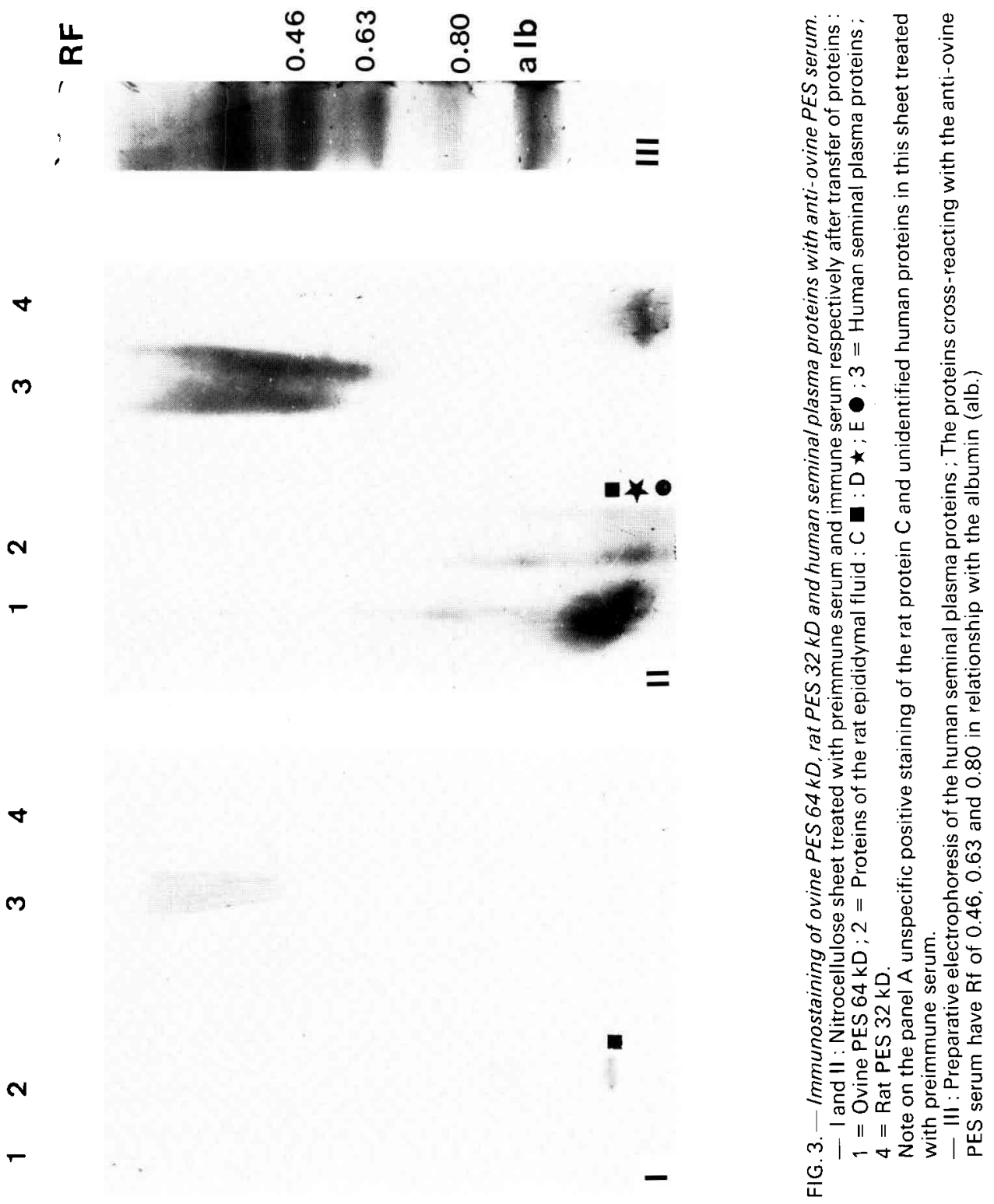

2. Localization on rat testis and epididymis. - Rat testis did not exhibit significant staining with the ovine PES 64 kD antibody. By contrast the intraluminal content of the proximal epididymis and the packed spermatozoa were heavily stained ; the stereocilia and the cytoplasm of the cells lining the duct were also stained; the staining decreased in the corpus and the cauda epididymidis (fig. 5.1A, 5.2A, 5.3A, 5.4A). The staining was specific as assessed by the absence of staining of controls treated with non-immune serum (fig. 5.2B, 5.3B, $5.4 \mathrm{~B})$. 

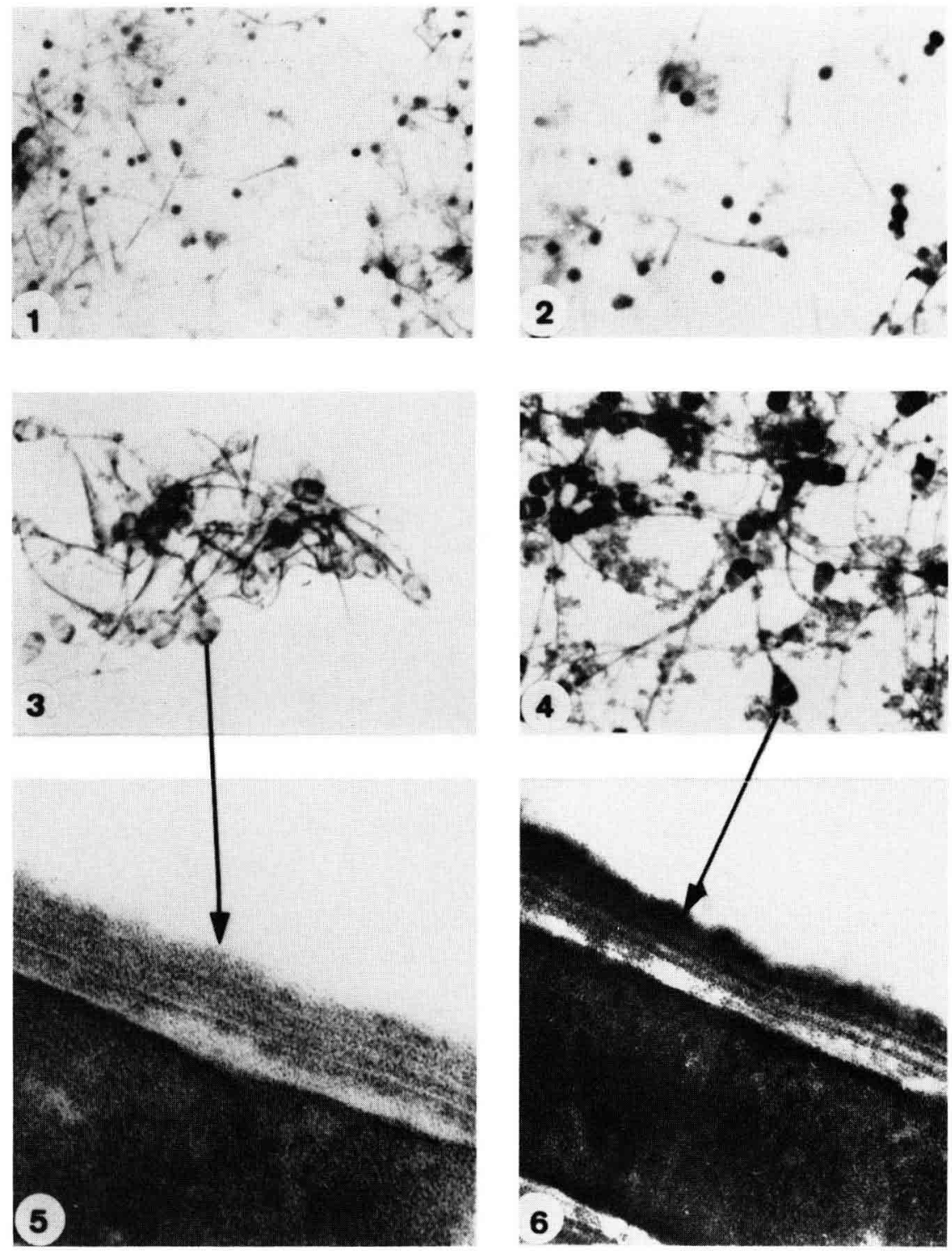

FIG. 4. - Immunocytological localization of ovine PES $64 \mathrm{kD}$ antigenic determinants on ram spermatozoa. FIG. 4.7 and 4.2: Unspecific labeling of the midpiece of testicular spermatozoa treated with preimmune (1) or immune (2) serum. FIG. 4.3 and 4.4: Specific labeling of periacrosomal area of ejaculated spermatozoa treated with preimmune serum (3) or immune serum (4).FIG. 4.5 and 4.6 : U/trastructural localization of the labeling of the plasma membrane from an aliquot of the sample presented on the picture 4.4 ; the control from an aliquot of the sample presented on the picture 4.3 is negative 4.5 . 

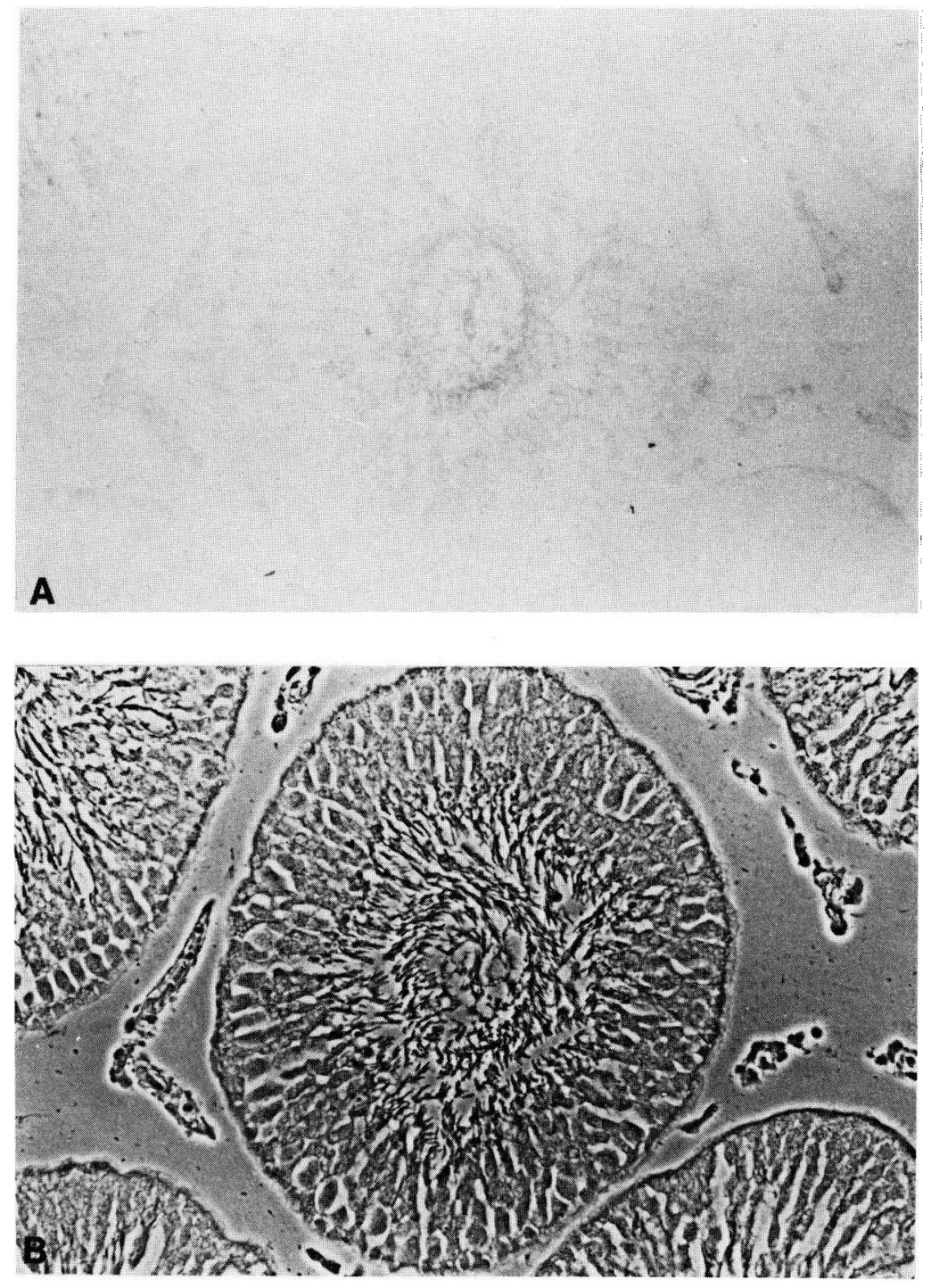

FIG. 5.1.

FIG. 5. - Immunocytological localization of ovine PES $64 k D$ epitopes on the testis and epididymis of the rat.FIG. 5.1: Testicular tissues treated with anti-ovine PES $64 \mathrm{kD}$ serum (A) do not exhibit significative staining on seminiferous tubules; (B) phase contrast.FIG. 5.2, 5.3, 5.4: Are representative of tissues of the proximal, middle or distal epididymis respectively. They were treated with anti-ovine PES $64 \mathrm{kD}$ serum (A), non immune serum (B) and observed under phase contrast (C). 


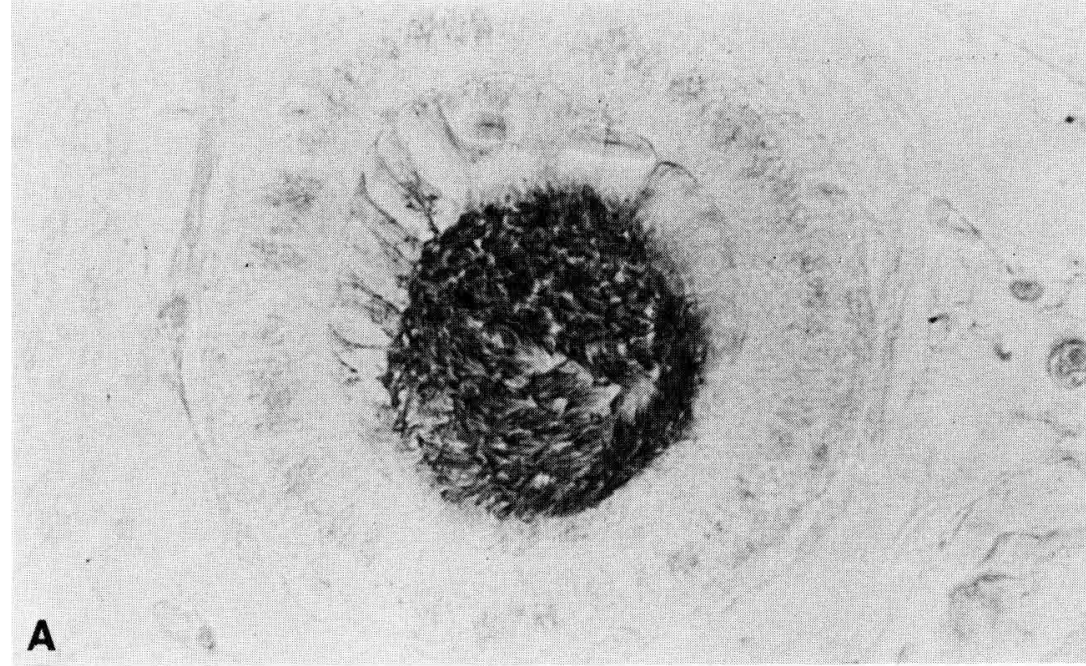

B

G. 5.2. - See legend p. 129 ?

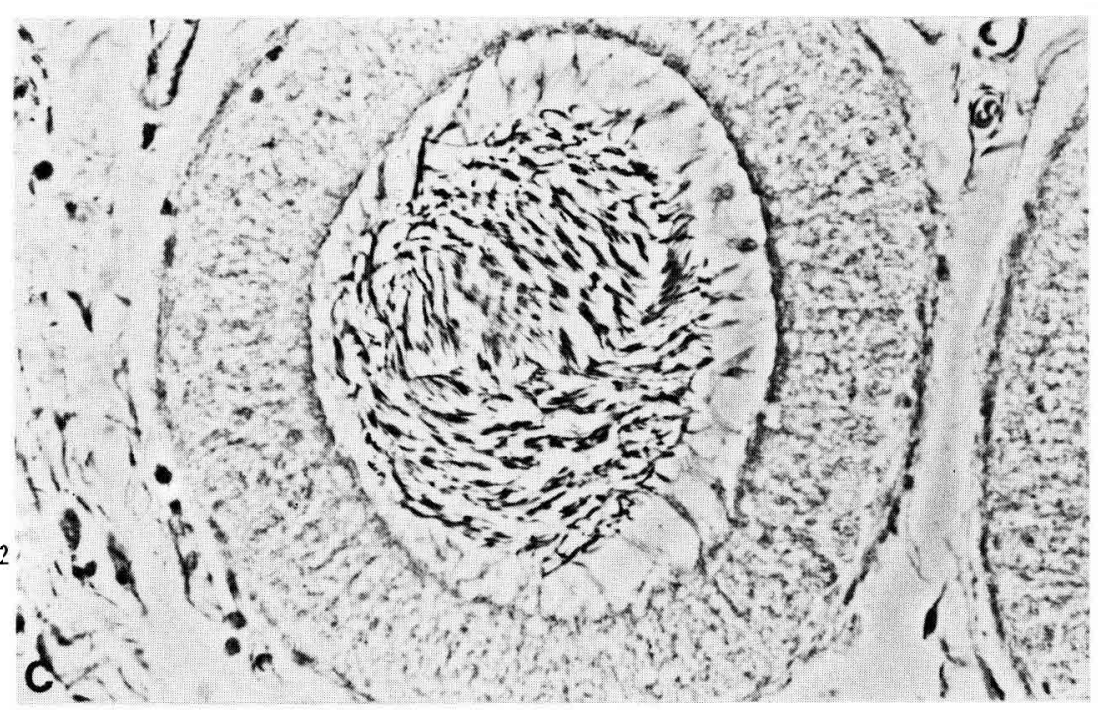



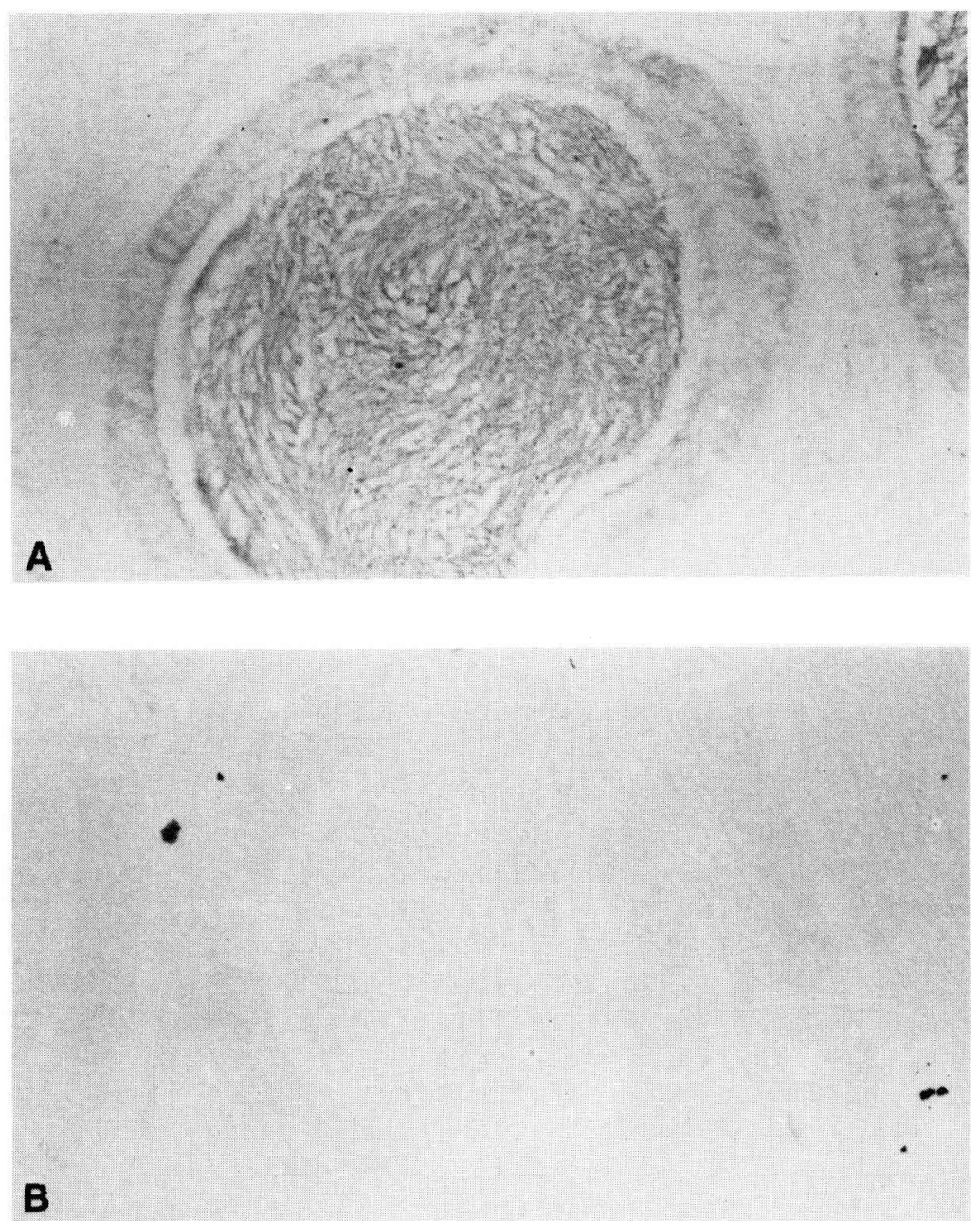

FIG. 5.3 - See legend p. $129 z$

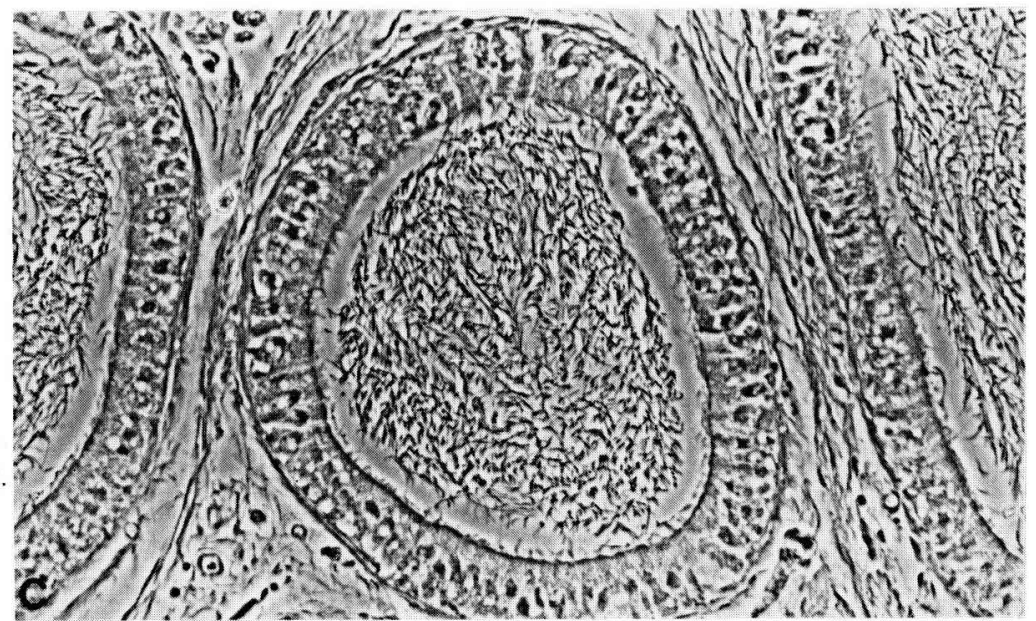



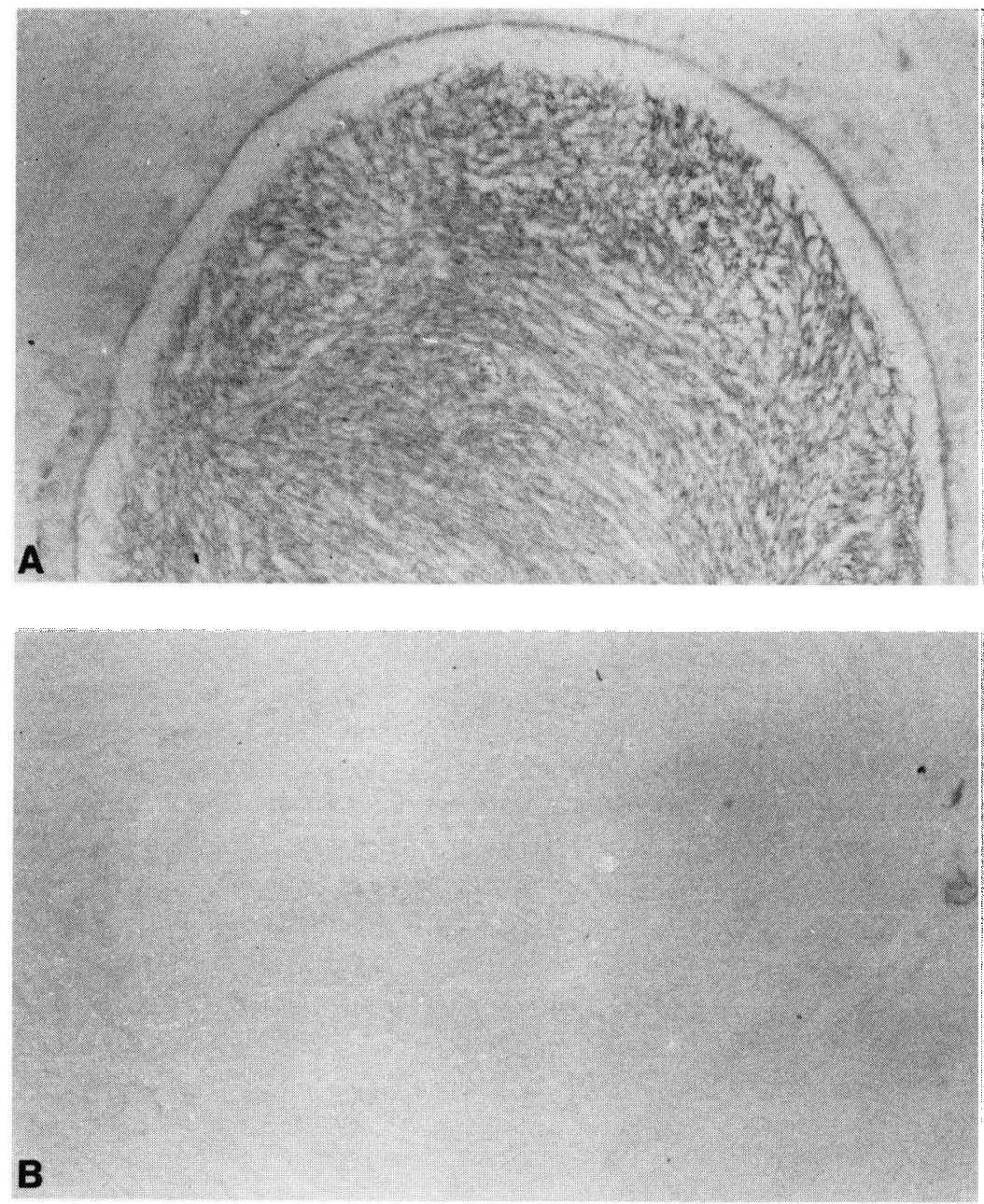

FIG. $5.4-$ See legend p. 1292

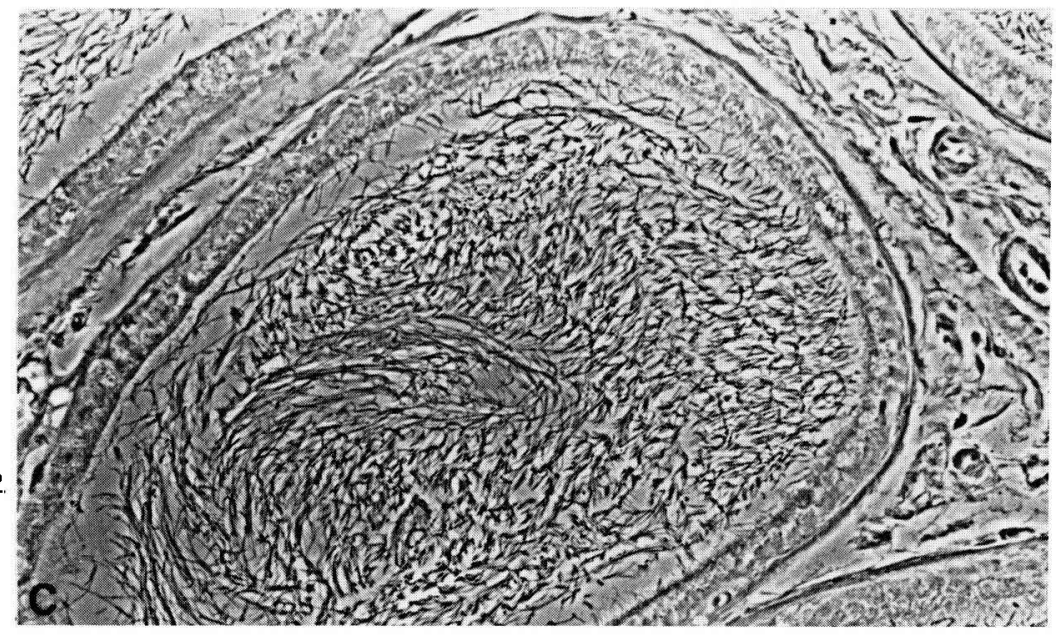


d. Preliminary amino acid analysis of rat PES, ovine PES, and human proteins having common antigenic determinants as revealed by the ovine PES antibody.

Amino acid analysis showed 244 amino acids per mole for rat PES $32 \mathrm{kD}$ and 509 per mole for ovine PES $64 \mathrm{kD}$ (table 1). The most prominent amino acid in both the rat and the ram protein was glycine. It was likely a contaminant from the preparative buffer still present despite extensive dialysis. The major amino acids in rat protein were serine, asparagine, alanine, leucine, threonine, valine, and proline. In ram protein, they were serine, alanine, glutamine, leucine, and threonine.

The human proteins 0.63 and 0.80 had similar amino acid compositions. The major amino acids were glutamine, serine, asparagine, lysine, leucine, and threonine.

TABLE 1

Relative amino-acid composition of rat PES $32 k D$, ram PES $64 k D$ and human seminal plasma protein $40 \mathrm{kD}(\mathrm{H} 5)$

\begin{tabular}{lccc}
\hline & Rat & Ram & Human \\
\hline Molecular weight & 27000 & 55000 & 40000 \\
\hline mol amino acid/ & & & \\
100 mol recovered & & & \\
- Asparagine & 14 & 3.6 & 13 \\
- Glutamine & 6 & 28 & 17 \\
- Serine & 19 & 3 & 13 \\
- Histidine & 2.4 & 3 & 7.9 \\
- Arginine & 3.5 & 6 & 4 \\
- Threonine & 7.5 & 13 & 5 \\
- Alanine & 8.5 & 1 & 2.3 \\
- Proline & 7.2 & 5 & 5.6 \\
- Tyrosine & 4.5 & 1 & 0 \\
- Valine & 7.6 & 2 & 3.4 \\
- Methionine & 0.4 & 2 & 4.2 \\
- Cysteine & 1.5 & 11 & 6.6 \\
- Isoleucine & 2 & 2 & 2.3 \\
- Leucine & 8.4 & 3 & 7.2 \\
- Phenylalanine & 2.7 & 5 & \\
- Lysine & 5 & & \\
\hline
\end{tabular}

Molecular weights estimated from 2D gel electrophoresis.

\section{Discussion.}

This work demonstrates that androgen-dependent proteins synthesized by the epididymis have interspecific epitopes which are both expressed in the cells of the epididymal epithelium (ram, rat), on the periacrosomal area of the plasma membrane of spermatozoa after entering into the epididymis (ram), and on specific proteins of rat epididymal plasma and human seminal plasma. 
The two proteins studied in the rat and in the ram have slightly lower molecular weight on 2-D SDS gel electrophoresis than on 1 -D SDS electrophoresis : $57 \mathrm{kD}$ versus $64 \mathrm{kD}$ for ovine PES $64 \mathrm{kD}$ protein and $27 \mathrm{kD}$ versus $32 \mathrm{kD}$ for the rat PES $32 \mathrm{kD}$ protein. This difference in molecular weight of rat protein has been reported previously (Brooks, 1982) and is likely an artifact of the electrophoresis conditions employed. The ovine and rat proteins had different isoelectric points : 7 for the ovine PES $64 \mathrm{kD}$ and 5.3 for the rat PES $32 \mathrm{kD}$. Brooks (1983) gave a similar isoelectric point for rat protein $D$. The number of amino acids (244) identified from the analysis of the rat PES $32 \mathrm{kD}$ protein in this study is in agreement with the number (246) obtained from the sequencing of the nucleic acids encoding for the synthesis of protein D (Brooks et al., 1986). The number of amino acids of the ovine PES $64 \mathrm{kD}$ is approximately double.

The antibody was specific for ovine PES $64 \mathrm{kD}$ since the preimmune or non-immune serum did not react with the protein on Western blots (fig. 3.1 and 3.II). This antibody cross-reacted with rat PES $32 \mathrm{kD}$ and with proteins $D$ and $E$ that represent the rat acid glycoprotein in the epididymal fluid; the latter is in agreement with Brooks' finding showing that proteins D and E shared common antigenic determinants (Brooks, 1982). Moreover, the antibody cross-reacted with two human seminal plasma proteins which migrated in the postalbumin area under non-denaturing electrophoresis; they could be related to epididymal proteins with same relative electrophoretic mobility which have been shown to associate with spermatozoa in the epididymis (Tezón et al., 1985). This implies that the ovine PES $64 \mathrm{kD}$ protein has epitopes common to analogous proteins in other species. This deserves further investigation, since hybridization data with cDNA to proteins D and E shows little cross species hybridization (Brooks et al., 1986). Amino acid analysis revealed a relative abundance of asparagine and serine/threonine which could support $\mathrm{N}$-glycosylation and $\mathrm{O}$-glycosylation, respectively. Therefore, the interspecific epitopes of ovine PES 64 kD protein may be glycoconjugates.

There is evidence of the expression of ovine PES $64 \mathrm{kD}$ antigenic determinants on the periacrosomal plasma membrane of ram epididymal spermatozoa. In this regard, the ovine PES $64 \mathrm{kD}$ protein is analogous to the rat PES $32 \mathrm{kD}$, since the latter has identical characteristics: secretion by the epididymis under androgenic stimulation and localization on the acrosomal surface on the concave area of the spermatozoa in the epididymis (Kohane et al,, 1979). Moreover, the anti-ovine PES serum did not stain testicular tissue but reacted heavily with the luminal content of the rat epididymis. The localization of the ovine PES $64 \mathrm{kD}$ antigenic determinants on rat epididymal spermatozoa, on human spermatozoa, and in human epididymal fluid remains to be determined. If the antigenic determinant present in human seminal plasma originates in the epididymis, it could become a useful marker of human epididymal function.

In conc/usion, it appears that the ovine epididymal protein PES $64 \mathrm{kD}$ shares antigenic determinants with both rat epididymal protein PES $32 \mathrm{kD}$ and human 
seminal plasma proteins. The biological function of these proteins remains to be determined.

\section{$5^{e}$ Congrès de la Société d'Andrologie} de langue française, Paris, décembre 1987.

Acknowledgments. - This investigation was supported in part by the Andrew W. Mellon Foundation and grants HD05797 and HD03820 from the National Institute of Child Health and Human Development and Institut National de la Recherche Agronomique (France).

The authors are grateful to Mrs. Delaleu for preparation of electron microscope samples in Nouzilly, to Dr. B. J. Danzo, Vanderbilt University, for useful discussion during the course of this investigation.

Résumé. Une protéine sécrétée par l'épididyme chez le bélier porte des déterminants antigéniques communs avec des protéines de l'épididyme du rat et du plasma séminal humain.

L'androgénodépendance de l'épithélium épididymaire de bélier a été établie par des observations ultrastructurales chez des animaux, 45 jours après la castration suivie ou non par un traitement avec des implants de testostérone durant 3 semaines. Une protéine épididymaire androgénodépendante caractérisée par sa migration dans la région des préalbumines en électrophorèse non dénaturante et dont le poids moléculaire de $64 \mathrm{kD}$ a été déterminé en gel SDS-PAGE (acrylamide 15\%) a été purifiée chez les animaux traités par l'hormone. Un antisérum monospécifique de cette protéine a présenté une réaction croisée avec la préalbumine 3 de rat (protéine $D-E$ ) et des protéines non identifiées du plasma séminal humain. L'analyse de la composition en acides aminés des protéines du rat, de l'homme et du bélier a montré des taux élevés d'aspartate, glutamate et sérine. La localisation immunocytochimique de ces protéines a été effectuée sur les spermatozoïdes épididymaires et testiculaires du rat, de l'homme et du bélier et sur les spermatozoïdes éjaculés du bélier, du taureau et de l'homme. Des déterminants antigéniques communs existeraient pour les protéines sécrétoires épididymaires qui manifestent une affinité pour les spermatozoïdes au cours de la maturation chez les mammifères.

\section{References}

AMANN R. P., 1987. Function of the epididymis in bulls and rams. J. Reprod. Fert., Suppl. 34, $115-131$

BROOKS D. E., 1982. Purification of rat epididymal proteins « $D$ » and « $E$ », demonstration of shared immunological determinants and identification of regional synthesis and secretion. Int. J. Androl., 5, 513-524.

BROOKS D. E., 1983. Effects of androgens on protein synthesis and secretion in various regions of the rat epididymis as analyzed by two-dimensional gel electrophoresis. Mol. cell. Endocrinol., 29, 225-270.

BROOKS D. E., MEANS A. R., WRIGHT E. J., SINGH S. P., TIVER K. K., 1986. Molecular cloning of the cDNA for androgen-dependent sperm-coating glycoproteins secreted by the rat epididymis. Eur. J. Biochem., 161, 13-18.

FAYE J. C., DUGUET L., MAZUCCA M., BAYARD F., 1980. Purification, radioimmunoassay and immunohistochemical localization of a glycoprotein produced by the rat epididymis. Biol. Reprod., 23, 423-432.

FOURNIER-DELPECH S., BAYARD F., BOULARD Cl., 1973. Etude d'une protéine spécifique du sperme épididymaire chez le rat; hormonodépendance, relation avec l'acide sialique. $C . R$. Soc. Biol., 163, 1989-1996. 
FOURNIER-DELPECH S., COUROT M., 1987. Sperm-zona binding capacity im mammals. In CLARKE J., Oxford reviews. Clarenton Press. Oxford, Vol. 9. 295-321.

FOURNIER-DELPECH S., PISSELET CI., GARNIER D. H., DUBOIS M. P., COUROT M., 1981. Mise en évidence chez le bélier d'une préalbumine sécrétée par l'épididyme sous l'action de la testostérone. C. R. Acad. Sci. Paris, Sér. III Vie, 193, 589-594.

FOURNIER-DELPECH S., VENIEN A., PISSELET CI., COUROT M., $1988 . \quad$ Localisation sur la tête des spermatozoìdes de Bélier de sites d'affinite pour la préalbumine épididymaire androgène-dépendante 64 kD; C. R. Acad. Sci. Paris, Sér. IIl Vie 306, 333-338.

GARBERI J. C., KOHANE A. C., CAMEO M. S., BLAQUIER J. A., 1979. Isolation and characterization of specific rat epididymal proteins. Mol. cell. Endocr., 13, 73-82.

HAMMERSTEDT R. H., PARKS J. E., 1987. Changes in sperm surface associated with epididymal transit. J. Reprod. Fert., Suppl. 34, 133-149.

JONES R., FOURNIER-DELPECH S., WILLADSEN S. A., 1982. Identification of androgendependent proteins synthesized in vitro by the ram epididymis. Reprod. Nutr. Develop., 22, 495-504.

KOHANE A. C., GARBERI J. C., CAMEO M. S., BLAQUIER J. A., 1979. Quantitative determination of specific proteins in rat epididymis. J. Steroid. Biochem., 11, 671-674.

LEA O. A., PETRUSZ P., FRENCH F. S., 1978. Purification and localization of acidic epididymal glycoprotein (AEG) : A sperm coating protein secreted by the rat epididymis. Int. J. Androl., Suppl. 2, 592-607.

ORGEBIN-CRIST M. C., 1986. Physiologie de l'épididyme et maturation du sperme : Etat actuel des connaissances; Contracept. Fert. Sex., 14, 487-495.

TEZON J. G., RAMELLA E., CAMEO M. S., VASQUEZ M. H., BLAQUIER J. A., 1985. Immunochemical localization of secretory antigens in the human epididymis and their association with spermatozoa. Biol. Reprod., 32, 591-597.

WONG P. Y., TSANG A. Y. F., 1982. Studies on the binding of a $32 \mathrm{kD}$ rat epididymal protein to rat epididymal spermatozoa. Biol. Reprod., 27, 1239-1246. 